\title{
Cell Adhesion Molecules and the Bronchial Epithelium
}

\author{
WILLIAM R. ROCHE, STEPHEN MONTEFORT, JANICE BAKER, and STEPHEN T. HOLGATE \\ Pathology and Immunopharmacology, University of Southampton General Hospital, Southampton, United Kingdom
}

\begin{abstract}
The bronchial epithelium is the major barrier between the host and the provoking antigens in bronchial asthma. Recent studies have indicated that the epithelium is a truly stratified structure, with the superficial columnar cells depending on the underlying basal cells for anchorage. Only columnar cells are shed into bronchial lavage fluid. The epithelium is more fragile in asthma and more cells are lost in clusters. Desmosomes appear to be the major structural adhesion mechanism at the plane of cleavage between the columnar cells and the basal cells. The $\alpha_{8}$ - and $\beta_{4}$-integrins, which contribute to hemidesmosomes and anchor cells to the underlying basement membrane, are expressed solely by basal cells. The apical aspects of the columnar cells are sealed by tight and intermediate junctions. There is constitutive expression of ICAM-1 and E-selectin in the vasculature of the bronchial mucosa, and ICAM is also present within the epithelium. These findings indicate that the bronchial epithelium is a complex structure that, as a mucosal surface, has constitutive expression of inflammatory cell adhesion molecules to serve normal leukocyte traffic. Roche WR, Montefort S, Baker J, Holgate ST. Cell adhesion molecules and the bronchial eplthellum. Am Rev Respir Dis 1993; 148(Suppl:S79-82).
\end{abstract}

The bronchial epithelium is a major interface between the host and its environment. The epithelium is exposed to both viruses and inhaled allergens, and it appears to be the focus of the inflammatory response that is characteristic of allergic asthma (1). The adhesion molecules in the bronchial epithelium may be divided into two groups, those whose primary function is maintaining the integrity of the epithelium and its contact with the underlying basement membrane, and those involved in leukocyte adhesion and migration (2).

The cell adhesion mechanisms in the bronchial epithelium deserve study for a number of reasons: the characteristic loss of bronchial epithelial cell integrity that is associated with bronchial asthma (3), the infiltration of the epithelium by mast cells, T-lymphocytes, and eosinophils in allergic asthma $(4,5)$, the potential physiologic consequences of epithelial cell loss such as the loss of modulation of smooth muscle function (6), and the immunologic consequences of increased epithelial permeability to allergen and cytokine production by the epithelium (7).

We have analyzed the cell adhesion mechanisms in bronchial asthma by two complementary approaches, the structural analysis of the epithelial defect in bronchial asthma and the immunohistochemical demonstration of the cell adhesion molecules within the epithelium (8). The aim of these studies was to define the mechanism whereby the epithelial defect characteristic of bronchial asthma is produced.

\section{THE STRUCTURE OF THE BRONCHIAL EPITHELIUM}

The bronchial epithelium has been regarded as a pseudostratified epithelium consisting of basal cells and superficial columnar

Correspondence and requests for reprints should be addressed to Dr. William R. Roche, Pathology, Level E, South Block, Southampton University General Hospital, Southampton SO9 $4 \mathrm{XY}$, UK.

Am Rev Respir Dis Vol 148. pp 579-\$82, 1993 cells that are either ciliated or secretory (9). Studies of the comparative microanatomy of the bronchial epithelium have questioned this model and have provided an alternative structure in which the basal cells function as sustentacular cells, the columnar cells are supported solely by the basal cells and do not themselves make significant contact with the basement membrane (10).

We have applied this model to the study of epithelial shedding in bronchial asthma. Examination of bronchial washings showed that asthmatics shed fourfold as many epithelial cells as do normal subjects when the bronchial epithelium is exposed to a 50$\mathrm{ml}$ warm saline wash (11). More epithelial cells were shed in cohesive clusters in the asthmatic population (figure 1), and these clusters also tended to be larger (12). Electron microscopy revealed that the clusters were entirely composed of columnar cells, confirming the appearance in bronchial biopsy (13) and autopsy material (14) in which the basal cells are retained on the epithelial basement membrane.

Electron microscopy of the bronchial epithelium has shown $\theta 0-$ sinophil leukocytes and their granules present within the widened intercellular spaces between the basal cells and superficial columnar cells in the bronchial epithelium $(11,13)$. The development of this plane of cleavage in asthma is in keeping with findings obtained by exposing guinea pig respiratory epithelium to eosinophil major basic protein which has been shown to induce detachment of the columnar cells from the basal cell layer at lower concentrations than those required to induce detachment of the basal cells from their basement membrane (15). Similarly, the epithelial cell damage associated with viral infections such as influenza also involves selective loss of the superficial epithelium (16), and experimental smoke exposure causes superficial desquamation of tracheal epithelium (17). We have not detected any increase in cells rendered permeable to the membrane permeability marker tannic acid, in biopsies from asthmatic subjects, suggesting that the epithelial cell shedding is due to selective disruption of adhesive mechanisms, rather than to lethal cytotoxic attack on the epithelial cells (18). 


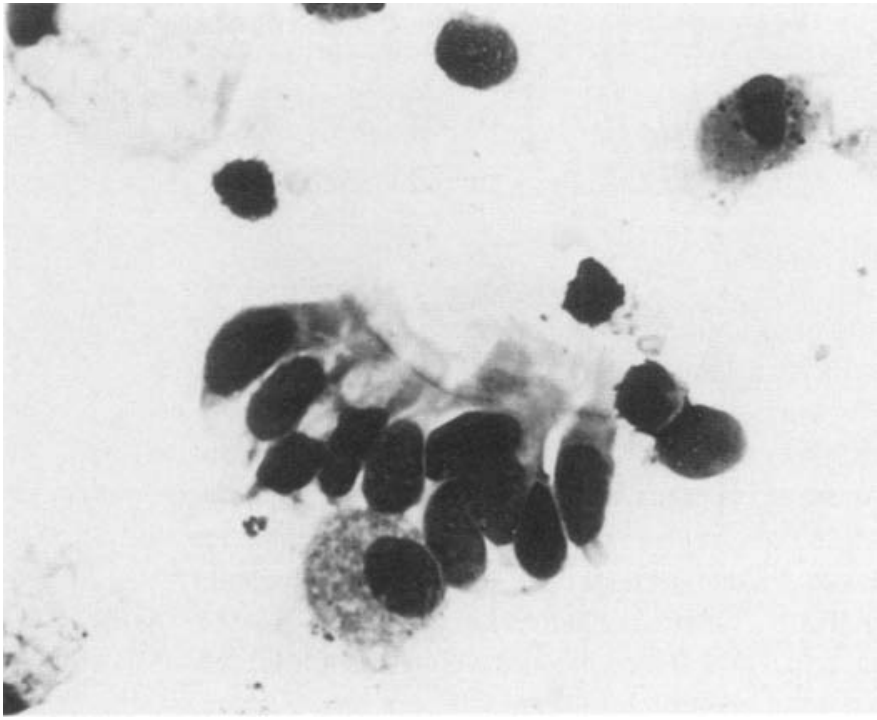

Figure 1. Cluster of ciliated bronchial epithelial cells from bronchial washings of an asthmatic subject (cytocentrifuge preparation; $\times 450$ ).

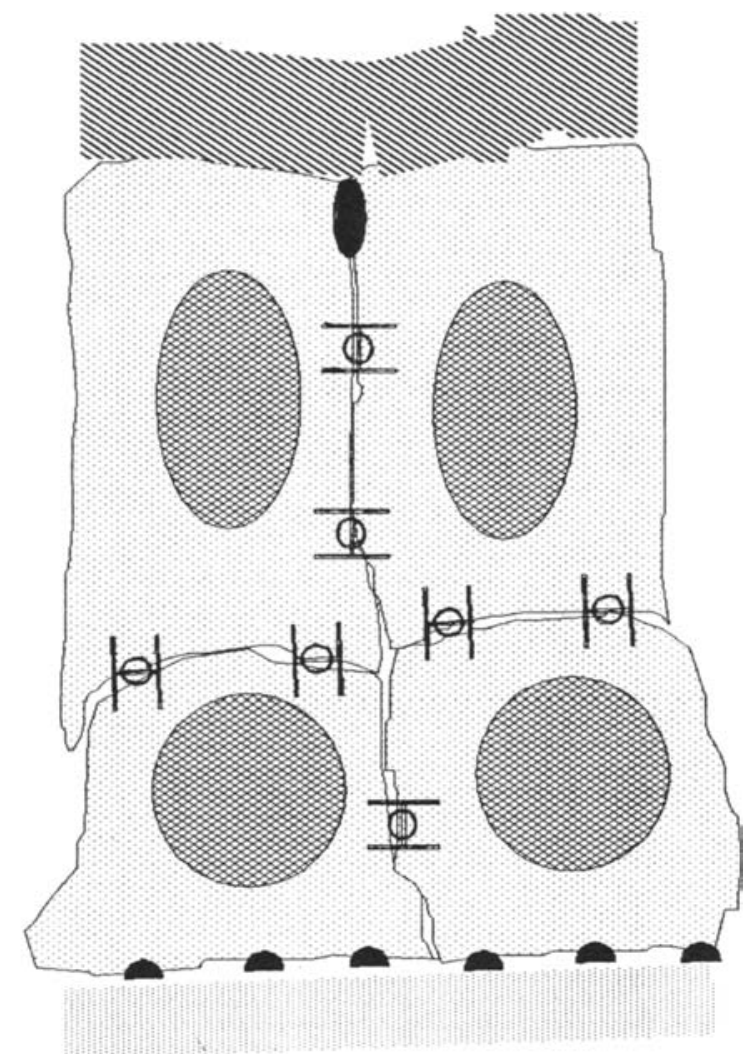

\section{Hemidesmosome}

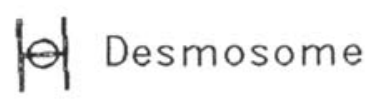

\section{Tight Junction}

Figure 2. Diagram showing the microanatomical relationship between columnar and basal cells in the bronchial epithelium and the location of the principal cell adhesion structures.

\section{ADHESION MECHANISM IN THE BRONCHIAL EPITHELIUM}

The classic structural approach to intercellular adhesion has, by the very nature of the method of investigation, stressed the importance of focal cell contacts: tight junctions, desmosomes, gap junctions, and hemidesmosomes (figure 2). Tight junctions between the columnar cells seal the apical aspects of the epithelium by surrounding the columnar cells. Deep to the tight junction there is another electron-dense zone termed the intermediate junction. It is likely that these structures regulate paracellular transport and the permeability of the epithelium.

Desmosomes are present along the lateral borders of the suprabasal cells and at the interface between the suprabasal and basal cells. These structures have a characteristic ultrastructural appearance with a laminar arrangement of intercellular glycoproteins, plaque proteins, and radiating tonofilaments (19). The availability of monoclonal antibodies to desmosomal proteins and glycoproteins enables these structures to be identified at light microscopy (20). Primary observations with such reagents have demonstrated the presence of desmosomes between the lateral aspects of the columnar cells and particularly at the junction of the basal and columnar cell layer (figure 3 ).

Hemidesmosomes are confined to the contact between the basal cells and the underlying basement membrane. The presence of the $\alpha_{B}$ - and $\beta_{4}$-integrins (see below) in the hemidesmosome indicates the importance of these structures to the bonding of the epithelium to the laminin of the basement membrane (21).

\section{STRUCTURAL CELL ADHESION MOLECULES IN THE BRONCHIAL EPITHELIUM}

Molecular cloning has advanced the knowledge of the cell adhesion molecules far more rapidly than possible by conventional techniques. The main families of molecules to be mapped to the bronchial epithelium are the integrins, the cadherins, and the cell surface proteoglycans/cartilage link protein family (CD44) (2). The integrins, which have already been discussed in this workshop, consist of transmembrane heterodimers composed of alpha and beta subunits. The integrins are not uniformly distributed in the bronchial epithelium but show specific localization patterns, some of which require that the integrins act as other than receptors for extracellular matrix.

Using a combination of immunofluorescence and enzyme immunohistochemistry on both frozen sections and tissue embedded in the water-soluble resin glycol methacrylate, we have mapped the integrins within the epithelium. The $\alpha_{B}$-and $\beta_{4}$-integrin molecules are distributed along the inferior border of the basal cells (figure 3), consistent with their localization to the hemidesmosome (21). The $\alpha_{2}$-integrin chain, which associates with the $B_{1}$-chain to form collagen and laminin receptors, was also found at the basal cell-basement membrane interface, but it was also present at the junction between basal cells and columnar cells and between the columnar cells along their lateral surfaces. This finding is in keeping with the published observations of others (22), and it would suggest that these molecules may have ligands other than the basement membrane components. It is of interest that the staining pattern of the $\alpha_{2}$-integrin chain was not represented at the interface between basal cells and the columnar cells, and this may be important to the epithelial disruption that occurs at that site. We did not detect the expression of $\alpha_{5}$ - or $\alpha_{5}$-integrins within the bronchial epithelium, although others have described faint immunohistochemical reactivity for $\alpha_{4}$-integrins in the bronchial epithelium (22) and $\dot{\alpha}_{5}$-integrins have been reported as being expressed by cultured epithelial cells (23). 

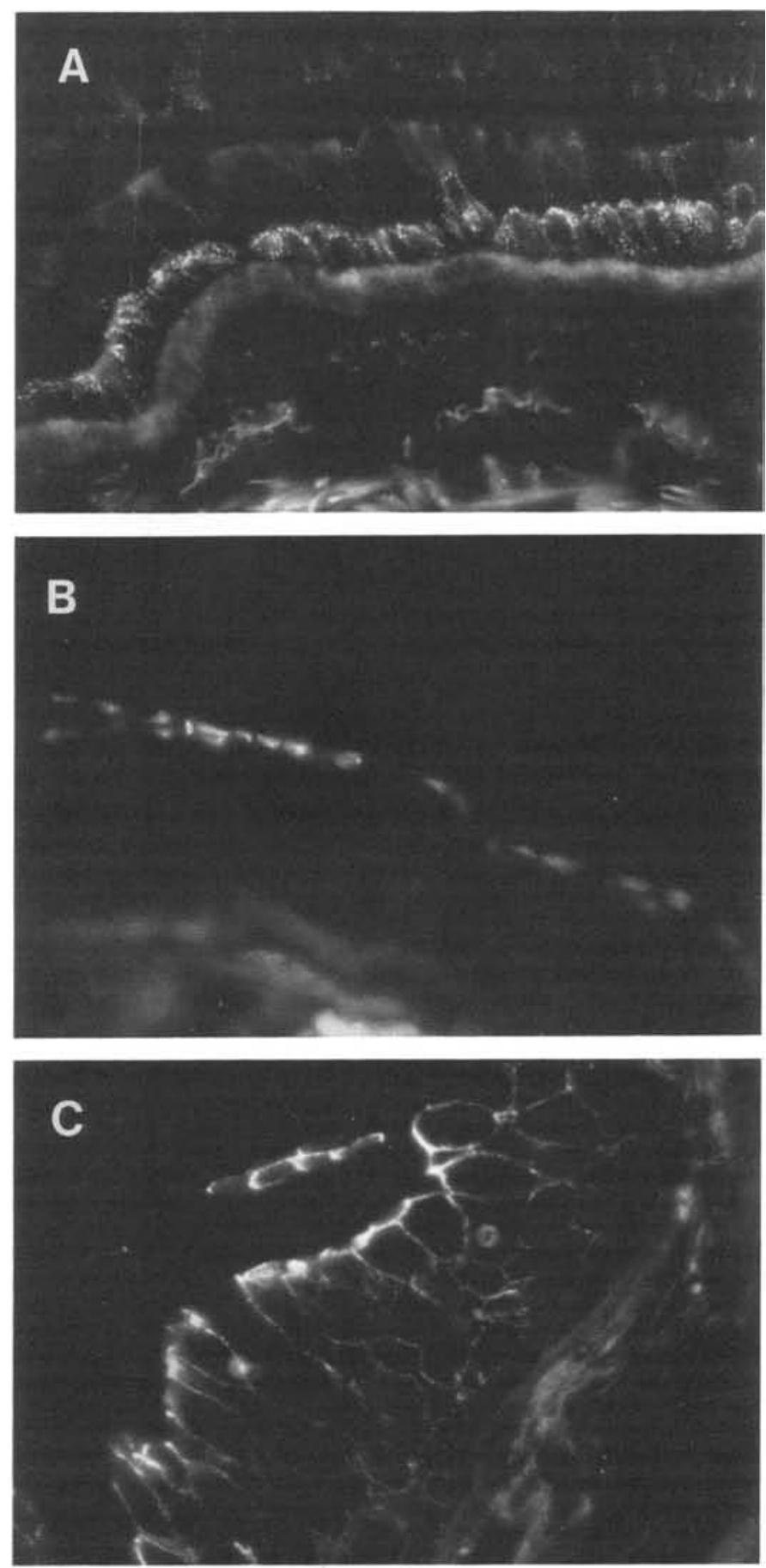

D
The monoclonal antibody ZO-1 demonstrated the tight junctions at the lateral apices of the epithelial cells, whereas the immunoreactivity for the cadherin uvomorulin extended inferiorly along the lateral cell membranes (figure 3), in keeping with its distribution in intermediate junctions (24).

\section{INDUCIBLE CELL ADHESION MOLECULES}

We have also examined the expression of the immunoglobulin super family molecules, intercellular adhesion molecule-1 (ICAM-1), vascular cell adhesion molecule-1 (VCAM-1), and E-selectin (endothelial-leukocyte adhesion molecule-1, ELAM-1) (25). These molecules, which may be upregulated by inflammatory mediators, are important in the recruitment of inflammatory cells in the vasculature, and they may have an important role in the mucosal inflammation and airway responses in asthma (26). We examined the expression of ICAM-1 and ELAM-1 in normal subjects and symptomatic asthmatics, six of whom were reexamined 6 wk after treatment with inhaled corticosteroid (25). We found that with the use of frozen sections, we detected ICAM-1 in both the epithelium and the vasculature in normal subjects, asthmatics, and asthmatics who had received sufficient inhaled steroid to reduce the inflammatory cell infiltrate in their bronchi. Similarly, there was ELAM-1 expression in the vasculature of both normal and asthmatic subjects, and this appeared to be unaffected by corticosteroid administration.

These results with the inducible cell adhesion molecules serve to remind us that the bronchial mucosa has a normal turnover of leukocytes as part of the host defense, that the recruitment of cells into the mucosa is a complex process, and that there may be critical steps that can be modulated by therapy other than those involving cell adhesion (27). We have, however, preliminary data to indicate that local allergen challenge does upregulate the expression of the bronchial mucosa, although we have yet to see significant changes in the expression of VCAM-1.

\section{CONCLUSIONS}

These descriptive studies of cell adhesion molecule expression in the bronchial epithelium have indicated areas that require further investigation. First, the molecular basis for the potential defect in columnar cell-basal cell adhesion in the bronchial epithelium and the specific mechanisms of attack upon this require to be identified. These may well be targets for therapeutic manipulation in the future. Second, we need more sophisticated models for cell recruitment into the epithelium than are currently available based on immunohistochemical demonstration of cell adhesion molecules. Although modeling of the stratified bronchial epithelium in culture will undoubtedly prove to be more difficult than leukocyte-endothelial cell adhesion, the dynamics of leukocyte infiltration of the endothelium, including the secretion of local chemotactic factors, require to be investigated if we are to understand the modulation of allergic inflammation.

Figure 3. Immunofluorescent localization of cell adhesion molecules in the human bronchus. A. Desmosomal proteins 1 and 2 showing a concentration of desmosomes at the junction between columnar and basal cells. B. Monoclonal antibody ZO-1 demonstrating tight junctions between columnar cells. C. E-cadherin showing intercellular distribution, particularly at the apical aspects of the lateral junctions of columnar cells. D. $\alpha_{\theta}$-integrin showing distribution at the junction of basal cells with the bronchial basement membrane, consistent with the distribution of hemidesmosomes $(x 450)$. 
Acknowledgment: We thank Professor David Garrod, Dr. Tom Fleming, Dr. Dorian Haskard, and Professor Tak Lee for supplying some of the antibodies used in our studies.

\section{References}

1. Djukanovic R, Roche WR, Wilson JW, Beasley CRW, Twentyman OP, Howarth PH, Holgate ST. Mucosal inflammation in asthma. Am Rev Respir Dis 1990; 142:434-57.

2. Albelda SM. Endothelial and epithelial cell adhesion molecules. Am J Respir Cell Mol Biol 1991; 4:195-203.

3. Naylor B. The shedding of the mucosa of the bronchial tree in asthma. Thorax 1962; 17:69-72.

4. Djukanovic R, Wilson JW, Britten KM, Wilson SJ, Walls AF, Roche WR, Howarth PH, Holgate ST. Quantitation of mast cells and eosinophils in the bronchial mucosa of symptomatic atopic asthmatics and healthy control subjects using immunohistochemistry. Am Rev Respir Dis 1990; 142:863-71.

5. Laitinen LA, Laitinen A, Haahtela T. A comparative study of the effects of an inhaled corticosteroid, budesonide, and a beta 2-agonist, terbutaline, on airway inflammation in newly diagnosed asthma: a randomised double-blind, parallel-group controlled trial. J Allergy Clin Immunol 1992; 90:32-42.

6. Morrison KJ, Vanhoutte PM. Airway epithelial cell in the pathophysiology of asthma. Ann N Y Acad Sci 1991; 629:82-8.

7. Cox G, Ohtoshi T, Vancheri $C$, et al. Promotion of eosinophil survival by human bronchial epithelial cells and its modulation by steroids. Am J Respir Cell Mol Biol 1991; 4:525-31.

8. Montefort S, Baker J, Holgate ST, Roche WR. Cell adhesion molecules in the bronchial epithelium (abstract). J Pathol 1992; 167:254A.

9. Kuhn C III. Normal anatomy and histology. In: Thurlbeck WM, ed. Pathology of the lung. New York: Tieme, 1988; 11-50.

10. Evans MJ, Cox RA, Shami SG, Wilson B, Plopper CG. The role of basal cells in attachment of columnar cells to the basal lamina of the trachea. Am J Respir Cell Mol Biol 1989; 1:463-9.

11. Beasley R, Roche WR, Roberts JA, Holgate ST. Cellular events in the bronchi in mild asthma and after bronchial provocation. Am Rev Respir Dis 1989; 139:806-17.

12. Montefort S, Roberts JA, Beasley R, Holgate ST, Roche WR. The site of disruption of the bronchial epithelium in asthmatic and non-asthmatic subjects. Thorax 1992; 47:499-503.

13. Laitinen LA, Heino $M$, Laitinen A, Kava T, Haahtela T. Damage of the airway epithelium and bronchial reactivity in patients with asthma. Am Rev Respir Dis 1985; 131:599-606.
14. Dunnill MS. The pathology of asthma with specific reference to changes in the bronchial mucosa. J Clin Pathol 1960; 13:27-33.

15. Frigas SE, Loergering DA, Gleich GJ. Cytotoxic effects of the guinea pig major basic protein on tracheal epithelium. Lab Invest 1980; 42:35-43.

16. Hers JFP. Disturbances of the ciliated epithelium due to influenza virus. Am Rev Respir Dis 1966; 93:162-71.

17. Abdi S, Evans MJ, Cox RA, Lubbesmeyer H, Herndon DN, Traber DL. Inhajation injury to tracheal epithelium in an ovine model of cotton smoke exposure. Early phase (30 minutes). Am Rev Respir Dis 1990; 142 1436-9.

18. Montefort S, Djukanovic R, Holgate ST, Roche WR. Ciliated cell damage in the bronchial epithelium of asthmatics and non-asthmatics. Clin Exp Allergy 1993; 23:185-9.

19. Miller K, Mattey DL, Measures H, Hopkins C, Garrod DR. Localisation of the protein and glycoprotein components of bovine nasal epithelial desmosomes by immunoelectron microscopy. EMBO J 1987; 6:855-9.

20. Vilela MJ, Parrish EP, Wright DH, Garrod DR. Monoclonal antibody to desmosomal glycoprotein 1. A new epithelial marker for diagnostic pathology. J Pathol 1987; 153:365-75.

21. Stepp MA. Spurr-Michaud S, Tisdale A, Elwell J, Gipson IK. $\alpha_{s} \beta_{2}$ integrin heterodimer is a component of hemidesmosomes. Proc Natl Acad Sci USA 1990; 87:8970-74.

22. Damjanovich L, Albeida SM, Mette SA, Buck CA. Distribution of the integrin cell adhesion receptors in normal and malignant lung tissue. Am J Respir Cell Mol Biol 1992; 6:197-206.

23. Sapsford RJ, Devalia JL, McAulay AE, d'Ardenne AJ, Davies RJ. Expression of a 1-6 integrin cell surface receptors in normal human bronchial biopsies and cultured bronchial epithelial cells (abstract). J Allergy Clin Immunol 1991; 87S:A303.

24. Boller K, Vestweber D, Kemler R. Cell-adhesion molecule uvomorulin is localised in the intermediate junctions of adult mouse intestinal epithelial cells. J Cell Biol 1985; 100:327-32.

25. Montefort S, Roche WR, Howarth PH, Djukanovic R, Gratziou C, Carroll M, Smith L, Britten KM, Haskard D, Lee TH, Holgate ST. Intercellular adhesion molecule-1 (ICAM-1) and endothelial leucocyte adhesion molecule-1 (ELAM-1) expression in the bronchial mucosa of normal and asthmatic subjects. Eur Respir J 1992; 5:815-23.

26. Gundel RH, Wegner CD, Torcellini CA, Clarke CC, Haynes N, Rothlein $R$, Smith CW, Letts LG. Endothelial leukocyte adhesion molecule-1 mediates antigen-induced acute airway inflammation and late-phase airway obstruction in monkeys. J Clin Invest 1991; 88:1407-11.

27. Morland CM, Wilson SJ, Holgate ST, Roche WR. Selective eosinophil recruitment by transendothelial migration and not by leukocyteendothelial cell adhesion. Am J Respir Cell Mol Biol 1992; 6:557-66. 